\title{
Relative lymphocyte count as an indicator of 3-year mortality in elderly people with severe COPD
}

\author{
Domenico Acanfora', Pietro Scicchitano ${ }^{2 *}$ (D), Mauro Carone ${ }^{1}$, Chiara Acanfora', Giuseppe Piscosquito', \\ Roberto Maestri ${ }^{3}$, Annapaola Zito ${ }^{2}$, llaria Dentamaro ${ }^{2}$, Marialaura Longobardi', Gerardo Casucci ${ }^{4}$, \\ Raffaele Antonelli-Incalzi $i^{5}$ and Marco Matteo Ciccone ${ }^{2}$
}

\begin{abstract}
Background: Prognostic stratification of elderly patients with chronic obstructive pulmonary disease (COPD) is difficult due to the wide inter-individual variability in the course of the disease. No marker can exactly stratify the evolution and natural history of COPD patients. Studies have shown that leukocyte count is associated with increased risk of mortality in COPD patients. The aim of this study was to evaluate the possible role of relative lymphocyte count as a risk marker for mortality in elderly patients with COPD.

Methods and results: This is a3-year prospective study. A total of 218patients, mean age $75.2 \pm 7$ years, with moderate to severe COPD and free from conditions affecting lymphocyte count were enrolled. The population was divided into two groups according to the relative lymphocyte count, with a cut-off of $20 \%$. Eighty-five patients (39\%) had a relative lymphocyte count $\leq 20 \%$. Three-year mortality rates from any cause in patients with relative lymphocyte count $\leq$ or $>20 \%$ were 68 and 51\%, respectively $(p=0.0012)$. Survival curve analysis showed higher mortality in patients with relative lymphocyte count $\leq 20 \%(p=0.0005)$. After adjustment for age and sex, the hazard ratio for mortality risk according to lymphocyte count was 1.79 (95\% confidence interval [Cl]: 1.26-2.57, $p=0.0013$ ), even in the analysis limited to the 171 patients without congestive heart failure $(1.63 ; 95 \% \mathrm{Cl}: 1.03-2.58, p=0.038)$.

Conclusions: Low relative lymphocyte count was associated with higher mortality in elderly patients with severe COPD.
\end{abstract}

Keywords: Lymphocyte, Mortality, Elderly, COPD

\section{Background}

Chronic obstructive pulmonary disease (COPD) is a frequent cause of death in elderly patients.

Older age, reduced gas exchange and airflow obstruction, right atrial overload and ventricular overload and hypertrophy and selected comorbidities are the main negative prognostic indicators as they could account for early death in these patients [1-3].

The prognostic stratification of elderly patients with COPD is difficult due to wide inter-individual variability the course of the disease. No marker can exactly stratify

\footnotetext{
* Correspondence: piero.sc@hotmail.it; pietrosc.83@libero.it

${ }^{2}$ Section of Cardiovascular Diseases, Department of Emergency and Organ

Transplantation, School of Medicine, University of Bari, Bari, Italy

Full list of author information is available at the end of the article
}

the evolution and natural history of COPD patients. Therefore, efforts are made in order to detect new prognostic markers and to verify whether they substantially add further prognostic value to well-recognized indicators [2, 4, 5]. Incalzi et al. [2] identified electrocardiographic signs (S1S2S3 pattern or right atrial overload (RAO)) as able to predict survival rates in patients with COPD.

The common plasmatic measures and biomarkers such as (procalctionin (PCT), C-reactive protein (CRP), white blood cell count (WBC)) are not able to reproducibly predict mortality in COPD patients [4].

Variables reflecting either inflammation or immune depression emerged as possible prognostic markers in patients with COPD. The increase in leukocyte count in peripheral blood shows a statistical trend towards the

(C) The Author(s). 2018 Open Access This article is distributed under the terms of the Creative Commons Attribution 4.0 International License (http://creativecommons.org/licenses/by/4.0/), which permits unrestricted use, distribution, and 
prediction of long-term all-cause mortality risk in COPD patients but it did not reach a statistical significance in previous studies $[4,6]$.

More insights come from the analysis of reduced WBCs and, in particular, lymphocyte count. A low relative lymphocyte count is already known to exert a detrimental prognostic role in the setting of acute myocardial infarction, stable coronary heart disease and congestive heart failure [7-11]. It also has a negative prognostic role in the elderly population [12], and, to some extent, it could be considered as a marker of the stress response [13, 14]. Although a low relative lymphocyte count is a physiological adaptation of the immune system to increasing age, it may account for the frailty of elderly people compared with younger individuals [15-17]. As patients with COPD may show a further decrease in lymphocyte count $[18,19]$, elderly individuals with COPD may have a combined reduction in lymphocytes due to both age and characteristics of the pulmonary disease.

Despite the established role of low relative lymphocyte count in many diseases, its prognostic value remains to be specifically evaluated in elderly patients with COPD.

The aim of the present study was to investigate the prognostic value of relative lymphocyte count in elderly patients with COPD.

\section{Methods \\ Patients}

The study was conducted on elderly patients with COPD who were consecutively admitted to our Institute for Research and Care related to Cardiac and Pulmonary Rehabilitation. The diagnosis of COPD was made according to American Thoracic Society (ATS) criteria [20]. A total of 218 patients (114 men and 104 women), mean age $75.2 \pm 7$ years, were recruited from October 1, 2011 to March 30, 2012.

Inclusion criteria were: age $\geq 65$ years and presence of severe and very severe COPD, as identified by ATS criteria [20]. Severe COPD was defined in agreement with forced expiratory volume in the 1st second (FEV1) $\leq 50 \%$ of predicted value. Patients were excluded if they were lacking complete blood count within 1 week of study entry, or on the basis of conditions known to affect lymphocyte count $[12,13]$ : recent coronary revascularization or recent myocardial infarction (within 6 months of entry), long-term disorders of the hemopoietic system, history of malignancy, chemotherapy, or radiation therapy, trauma, surgery, infection and glucocorticoid therapy within 6 weeks of study entry. Patients were also excluded if dyspnoea, phlegm or weakness had worsened in the two weeks prior to admission. This precautionary measure was utilized to limit the risk of enrolling patients with exacerbated COPD.

\section{Study design}

Extensive baseline data were collected for all eligible patients within one week of hospital admission. Patients underwent physical examination, spirometry, chest X-ray, arterial blood gas analysis, electrocardiogram and laboratory tests (including complete blood count); their clinical history was accurately recorded. Spirometry was performed with a VMAX 2200 spirometer (Sensor Medics Co., Yorba Linda, USA), meeting the American College of Physicians, American College of Chest Physicians, American Thoracic Society, and European Respiratory Society 2011 recommendations for diagnostic spirometry [20, 21]. Arterial blood gas analysis was performed (during room air breathing) with an ABL 520 Radiometer analyzer (Copenhagen, Denmark).

Patients' characteristics were reported: age, gender, body mass index, history of smoking (defined as subjects who had regularly smoked at least 5 cigarettes/day during the previous 3 months or who had stopped smoking less than 1 year before admittance into our study), alcohol use, lung function $\left[\mathrm{FEV}_{1}\right.$, forced vital capacity (FVC), both in milliliters and as percent of predicted], arterial blood gases [partial arterial oxygen tension $\left(\mathrm{PaO}_{2}\right)$, partial arterial carbon dioxide tension $\left.\left(\mathrm{PaCO}_{2}\right), \mathrm{pH}\right]$, presence of ischemic heart disease, history of myocardial infarction, congestive heart failure, diabetes, systemic hypertension, cerebro-vascular disease, peripheral vascular disease, use of bronchodilators, mucolytics and aminophylline, heart rate, systolic and diastolic blood pressure. None of the enrolled patients were in long-term oxygen therapy. Furthermore, their $\mathrm{PaO} 2(\mathrm{mmHg})$ at rest was $70.4 \pm 8 \mathrm{mmHg}$ (range 60 $91 \mathrm{mmHg})$.

Individual clinical history was diagnosed according to the International Classification of Diseases, Ninth Revision, Clinical Modification [22]. Patients were classified as affected by congestive heart failure only on the basis of a concordant diagnosis according to the physician's clinical judgment, Boston criteria [23] and a clinical diagnostic score which was previously validated on hospitalized patients [24]. We used this conservative diagnostic approach due to the great difficulty in distinguishing chronic cor pulmonare from congestive heart failure.

Baseline clinical evaluation, complete blood count, electrocardiography, lung function, blood gas analysis, and data on patient's clinical history were collected by a trained and experienced physician.

\section{Follow-up}

The follow-up covered a period of 36 months after hospital discharge. Physicians phoned all the patients at $6,12,24$ and 36 months after hospital discharge in order to assess the data regarding their health condition. In particular, the primary end-point of the study was "death from any cause". 
Death certificates and hospital records were considered and checked when patients and/or relatives were not available for phone recall. All available data were reviewed by two investigators (DA, MMC) to determine and define the cause of death. If a consensus of opinion could not be reached, the opinion of the senior investigator (RAI) prevailed.

\section{Laboratory methods}

All patients underwent complete blood count evaluation and a leukocyte differential count analysis at baseline. The percentage of lymphocytes was defined as: (total lymphocytes/total leukocytes $) \times 100$. In our laboratories, the normal range of the percentage of lymphocytes is 20 to $50 \%$, as defined by the central $95 \%$ range in a separate population of 52 healthy adults [11].

We evaluated the short- and long-term reproducibility of relative lymphocyte count by considering three blood samples from 24 healthy volunteers over a period of 360 days, spaced at $6 \pm 1$ and $136 \pm 67$ days.

\section{Study approval}

All procedures were in accordance with the ethical standards of the institutional research committee and with the 1964 Declaration of Helsinki. Informed written consent was obtained from all individual participants included in the study.

\section{Statistical analysis}

Data analysis was performed with SPSS software (SPSS, Chicago, USA). Results were given as means ( \pm standard deviation) for continuous variables or as percentages for dichotomous variables.

Short-term and long-term reproducibility of relative lymphocyte count was assessed by first testing for systematic changes, between baseline and second measurement, and between baseline and the final measurement, respectively. To quantify the reproducibility, we used the standard error of measurement, which was computed as the root mean square error of the 1-way random effects analysis of variance on short-term and long-term paired measurements. From the same 1-way analysis of variance, the intra-class correlation coefficient (an index of reliability of measurements) was derived and remained significantly higher at long-term follow-up (Additional file 1: Table S1).

Differences between groups were assessed by unpaired t-test or Mann-Whitney test for continuous variables with or without normal distribution and homogeneous variance, and by chi square test for dichotomous variables. Kaplan-Meier estimates of the survival functions were plotted for relative lymphocyte count [25]. Univariate and multivariate Cox regression models were used to investigate the association of selected variables with the incidence of death [26].
All hypothesis tests were tested using a significance level of 0.05 . All $p$-values were two-sided.

\section{Results}

Relative lymphocyte count showed high short- (standard error of measurement $=2.11$ ) and long-term (standard error of measurement $=1.15$ ) reproducibility. The estimates of intra-class correlation coefficient for the short(intra-class correlation coefficient $=0.95$ ) and long-term (intra-class correlation coefficient $=0.97$ ) indicated excellent reproducibility for the relative lymphocyte count measurement. These values indicate that obtaining a single sample from a subject is fairly representative of that individual's relative lymphocyte count over an extended period of time.

In the study sample, 85 patients (39\%) had relative lymphocyte counts $\leq 20 \%$.

The study sample included 218 patients with mean age of $75.2 \pm 7$ years, $52 \%$ male. The population sample was divided into two groups according to relative lymphocyte count: group 1 with relative lymphocyte count $\leq 20 \%$; group 2 with relative lymphocyte count $>20 \%$. About $39 \%$ of patients showed a relative lymphocyte count $\leq 20 \%$.

Demographic, respiratory function and clinical characteristics of the patients in the two groups are shown in Table 1. Groups did not differ according to demographic characteristics or anthropometric status, as expressed by body mass index (BMI). All of the patients were white Caucasic individuals. A lymphocyte count $\leq 20 \%$ was associated with a lower six-minute walking distance and higher basal heart rate (Additional file 2: Figure S1 and Additional file 3: Figure S2). The reproducibility of the white cells count can be observed in Additional file 1: Table S1.

Lung function indices were significantly lower in patients with relative lymphocyte count $\leq 20 \%$; the greatest difference was evident in FVC, expressed as a percentage of the predicted value. The FEV1/FVC index did not distinguish between groups because both terms in the ratio had reduced by a comparable extent in the two groups (Table 1).

Ischemic heart disease and previous myocardial infarction were less prevalent in patients with relative lymphocyte count $\leq 20 \%$ (group 1 ), while congestive heart failure, diabetes and chronic cor pulmonare were more prevalent in group 1. Neither arterial blood gases nor pharmacologic therapy distinguished between the groups, except for a slightly higher use of mucolytics by patients with a lymphocyte count $>20 \%$ (group 2).

Only one patient was lost at the 36-months follow-up time (he was known to be alive at 25th month follow up) and was censored. Mean follow-up time was 22 months, with 118 deaths. One- and 3-year survival rates were 67 and $42.2 \%$, respectively. Patients died from acute or chronic 
Table 1 Clinical characteristics in patients with severe COPD in relation to the relative lymphocyte count at baseline

\begin{tabular}{|c|c|c|c|}
\hline$\overline{V_{A R I A B L E}}{ }^{a}$ & $\begin{array}{l}\text { Relative } \\
\text { lymphocyte } \\
\text { count } \leq 20 \% \\
(N=85)\end{array}$ & $\begin{array}{l}\text { Relative } \\
\text { lymphocyte } \\
\text { count > 20\% } \\
(N=133)\end{array}$ & $p$-value \\
\hline $\operatorname{Sex}(M / F)$ & $46 / 39$ & $68 / 65$ & 0.67 \\
\hline Age (years) & $76 \pm 7$ & $74 \pm 7$ & 0.06 \\
\hline Bodymass index (BMI) & $25.7 \pm 5$ & $25.4 \pm 4$ & 0.66 \\
\hline History of smoking (n/\%) & $43(51 \%)$ & $72(54 \%)$ & 0.61 \\
\hline Alcohol use (n/\%) & $30(35 \%)$ & $48(36 \%)$ & 0.90 \\
\hline \multicolumn{4}{|l|}{ Lung Function } \\
\hline $\mathrm{FEV}_{1}(\mathrm{ml})$ & $762 \pm 268$ & $870 \pm 268$ & 0.004 \\
\hline $\mathrm{FEV}_{1}$ (percent of predicted) & $30 \pm 9$ & $34 \pm 8$ & 0.005 \\
\hline FVC (ml) & $1720 \pm 656$ & $2038 \pm 687$ & 0.001 \\
\hline FVC (percent of predicted) & $53 \pm 17$ & $62 \pm 17$ & $<0.0001$ \\
\hline $\mathrm{FEV}_{1} / \mathrm{FVC}$ (percent) & $47 \pm 13$ & $44 \pm 11$ & 0.16 \\
\hline \multicolumn{4}{|l|}{ Arterial Blood Gases } \\
\hline $\mathrm{PaO}_{2}(\mathrm{mmHg})$ & $71 \pm 9$ & $70 \pm 8$ & 0.79 \\
\hline $\mathrm{PaCO}_{2}(\mathrm{mmHg})$ & $38 \pm 5$ & $37 \pm 4$ & 0.12 \\
\hline $\mathrm{pH}$ & $7.40 \pm 0.39$ & $7.40 \pm 0.41$ & 0.47 \\
\hline \multicolumn{4}{|l|}{ Disease $(n / \%)$} \\
\hline Ischemic heart disease & $21(25 \%)$ & $49(37 \%)$ & 0.027 \\
\hline History of myocardial infarction & $20(24 \%)$ & $54(41 \%)$ & 0.0091 \\
\hline Congestive heart failure & $32(38 \%)$ & $15(11 \%)$ & 0.0001 \\
\hline Corpulmonale & $43(51 \%)$ & $49(37 \%)$ & 0.031 \\
\hline Diabetes & $19(22 \%)$ & $25(19 \%)$ & 0.52 \\
\hline Systemic hypertension & $40(47 \%)$ & $65(49 \%)$ & 0.79 \\
\hline Cerebro-vascular disease & $20(24 \%)$ & $32(24 \%)$ & 0.93 \\
\hline Peripheral vascular disease & $11(13 \%)$ & $17(13 \%)$ & 0.97 \\
\hline \multicolumn{4}{|l|}{ Therapy (n/\%) } \\
\hline Bronchodilators & $66(78 \%)$ & $100(75 \%)$ & 0.68 \\
\hline Mucolytics & $70(82 \%)$ & $101(76 \%)$ & 0.26 \\
\hline Aminophylline & $53(62 \%)$ & $112(69 \%)$ & 0.029 \\
\hline Heart rate (bpm) & $95 \pm 22$ & $82 \pm 19$ & $<0.0001$ \\
\hline Systolic blood pressure (mmHg) & $139 \pm 25$ & $142 \pm 20$ & 0.42 \\
\hline Diastolic blood pressure (mmHg) & $78 \pm 11$ & $81 \pm 9$ & 0.031 \\
\hline
\end{tabular}

Differences between groups were assessed by unpaired t-test or Mann-Whitney test for continuous variables having or not both normal distribution and homogeneous variance, and by the chi square test for dichotomous variables COPD chronic obstructive pulmonary disease, $F E V_{1}$ forced expiratory volume at $1 \mathrm{~s}, \mathrm{FVC}$ forced vital capacity, $\mathrm{FEV} / / \mathrm{FVC}$ Tiffeneau, $\mathrm{PaO}_{2}$ partial arterial oxygen tension, $\mathrm{PaCO}_{2}$ partial arterial carbon dioxide tension, $\mathrm{MI}$ myocardial infarction. Plus-minus values are means \pm SD

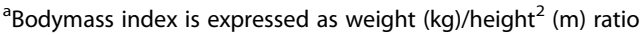

respiratory failure [34 (27\%)], acute myocardial infarction [31 (25\%)], stroke [21 (17\%)], cor pulmonare [12 (10\%)], respiratory infections $[10(8 \%)]$, cancer [9 (7\%)], sudden death [4 (3\%)], or other causes [5 (4\%)].

Low relative lymphocyte count at baseline was associated with an increased incidence of death from any causes [58 (68\%) vs. 68 (51\%); $p=0.0012$ ] (data not shown).

In the Additional file 4: Figure S3 the hazard ratio is shown as a function of relative lymphocyte count threshold. A clear maximum around $20 \%$ can be appreciated indicating this value as the optimal cutoff-point.

Table 2 compared causes of early (within 6 months from discharge) and late (after 6 months from discharge) mortality. Worsening of cardiopulmonary failure prevailed as a cause of early mortality, while acute myocardial infarction, stroke and cancer accounted for most late mortality.

Kaplan-Meier estimates of the probability of death are shown in Fig. 1a. Patients with relative lymphocyte count $\leq 20 \%$ had worse prognosis, which became evident in the earliest phases of the follow up and remained unchanged for the whole observation period.

The relationship between tertiles of relative lymphocyte count at study entry and 3-year mortality is shown in Fig. 1b. Mortality decreased significantly, from $69.3 \%$ in the first tertile to $45.7 \%$ in the third.

Table 3 outlines the results of Cox proportional-hazard model comparing mortality in patients with lymphocyte count $\leq 20$ and $>20 \%$. The age- and sex-adjusted hazard ratio was significantly different from 1.0, suggesting an excess of mortality in patients with lower relative lymphocyte count. The result remained statistically significant even after further adjustment for smoking, body mass index, FEV1 (percent of predicted) and also after adjusting for all variables potentially associated with death.

Table 4 shows the Cox proportional-hazard model limited to patients without a diagnosis of congestive heart failure. The hazard ratio for lymphocyte count $\leq 20 \%$ (group1) remained significant after excluding those with congestive heart failure.

\section{Discussion}

Relative lymphocyte count was significantly related to survival in elderly patients with moderate to severe COPD. The present findings are in agreement with those of Lehtonen et al. who found that a reduction in both $\mathrm{B}$ and $\mathrm{T}$ cells could predict mortality in very old

Table 2 Causes of early (0-6 months from discharge) and late (>6 months from discharge) mortality

\begin{tabular}{lll}
\hline Cause of death & $\mathrm{n}$ Early death & $\mathrm{n}$ Late death \\
\hline Progressive pulmonary failure & 44 & 12 \\
Acute myocardial infarction & 11 & 20 \\
Stroke & 8 & 13 \\
Cancer & 0 & 9 \\
Sudden death & 1 & 3 \\
Others & 2 & 3 \\
\hline
\end{tabular}

Pearson's $x^{2}=39.57, p<0.001$ 


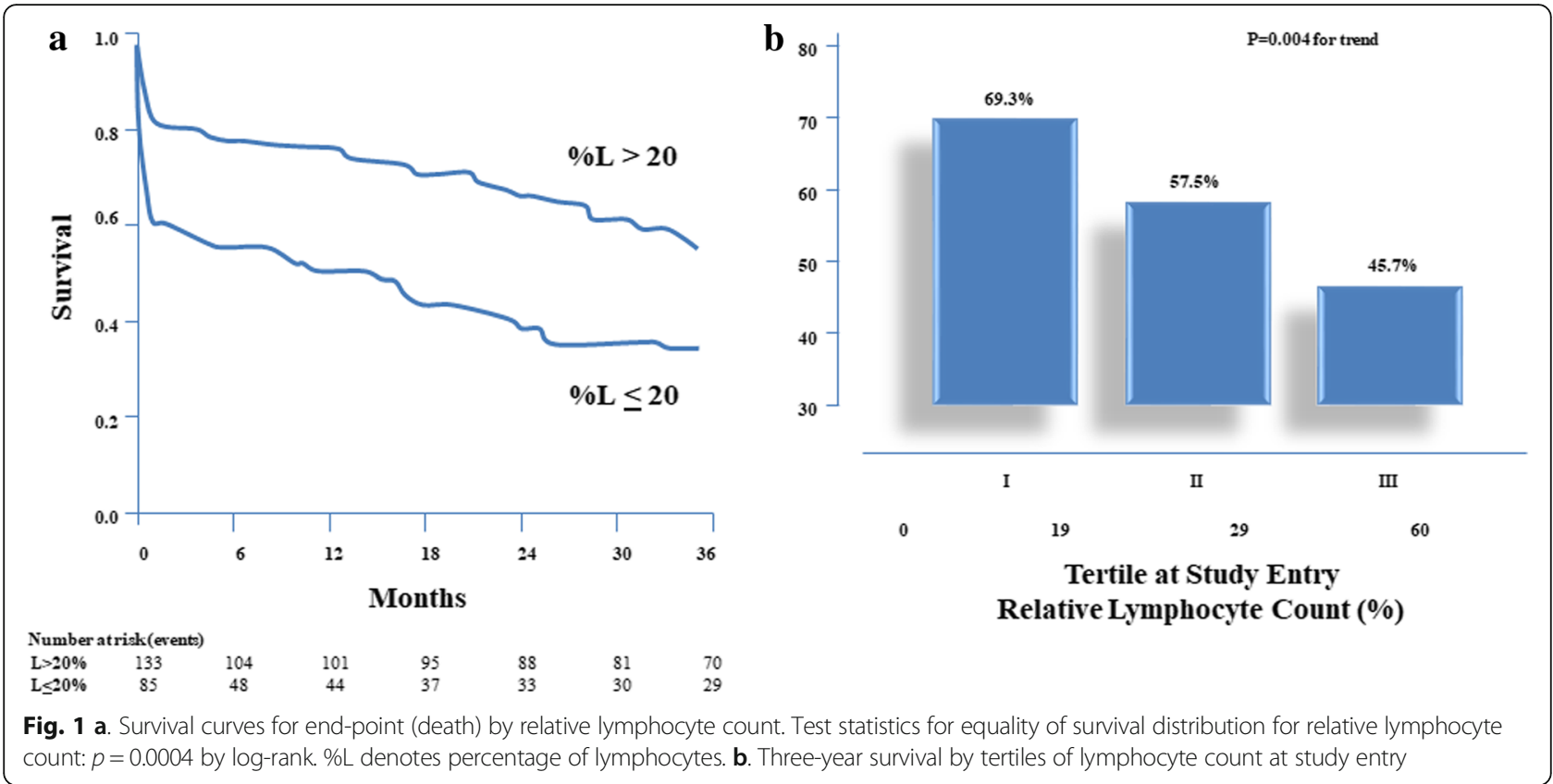

people with severe chronic illnesses [15]. The differences in survival at 1 and 3 years between groups with and without relative lymphopenia were similar, with the excess deaths in those with low relative lymphocyte count mostly due to very early events. Figure 1 shows that the difference in survival is early on, and the slopes are the same (i.e. the same relative death rate) from about 6 months afterwards.

Analysis of the causes of death shows that worsening of cardiopulmonary failure was responsible for most of the early deaths, whereas late mortality was related mainly to cardiovascular or cerebrovascular disease and cancer (Table 2). As a sign of impaired immunity, lymphopenia should carry a higher risk of infections, which are the main cause of fatal COPD exacerbations and, thus, should be related mainly to early mortality [5]. The significant difference in both early and late mortality between patients with and without lymphopenia suggests that reduced lymphocyte count qualifies as a comprehensive indicator of health status rather than as a pure immunologic marker. The very high mortality in the six months after discharge from a rehabilitation unit suggests that COPD should not be considered as a stable condition even if clinical judgment is consistent with such a diagnosis. Thus, careful supervision of patients with COPD seems desirable in order promptly to recognize and treat impending cardiopulmonary failure.

There are contradictory results regarding lymphocyte number and function in senescence $[15,27]$.

Rea et al. demonstrated a 10\% decrease in both B and $\mathrm{T}$ cell number and percentage of absolute lymphocyte count in elderly subjects [28]. According to B cells, the relative reduction in $\mathrm{B}$ cells can provoke alterations in the production of specific antibodies. As B cells can switch immunoglobulins among the different types and in agreement with specific actions toward the pathogenic agents, the reduction in B cell count can negatively affect outcome in elderly patients $[29,30]$. Furthermore, T cells can promote the production of cytokines able to enhance the response to pathogens from different actors in the immune

Table 3 Results of Cox proportional hazards model comparing mortality in patients with severe COPD with relative lymphocyte count $\leq 20 \%$

\begin{tabular}{|c|c|c|}
\hline Variable & $\begin{array}{l}\text { Hazard ratio for relative lymphocytes } \\
\text { count } \leq 20 \%(95 \% \mathrm{Cl})\end{array}$ & $p$-value \\
\hline Adjusted for age and sex & $1.81(1.27-2.59)$ & 0.0012 \\
\hline Adjusted for age, sex, smoking, body mass index, FEV ${ }_{1}$ (percent of predicted) & $1.79(1.22-2.62)$ & 0.003 \\
\hline $\begin{array}{l}\text { Adjusted for age, sex, smoking, body mass index, } \mathrm{FEV}_{1} \text { (percent of predicted), } \\
\mathrm{FVC} \text { (percent of predicted), } \mathrm{FEV} / \mathrm{FVC} \text { (percent), } \mathrm{PaO}_{2}, \mathrm{PaCO}_{2}, \mathrm{pH} \text {, ischemic } \\
\text { heart disease, history of myocardial infarction, congestive heart failure, } \\
\text { heart rate, systolic and diastolic blood pressure. }\end{array}$ & $1.56(1.02-2.38)$ & 0.04 \\
\hline
\end{tabular}

COPD chronic obstructive pulmonary disease, $C l$ confidence interval, $F E V_{1}$ forced expiratory volume in one second, FVC forced vital capacity, FEV ${ }_{1} / F V C$ Tiffeneau, $\mathrm{PaO}_{2}$ partial arterial oxygen tension, $\mathrm{PaCO}_{2}$ partial arterial carbon dioxide tension 
Table 4 Results of Cox proportional hazards model comparing mortality in COPD patients free from CHF with relative lymphocyte count $\leq 20 \%$

\begin{tabular}{lll}
\hline Variable & $\begin{array}{l}\text { Hazard ratio for relative lymphocytes } \\
\text { count } \leq 20 \%(95 \% \mathrm{Cl})\end{array}$ & $p$-value \\
\hline Adjusted for age and sex & $1.65(1.04-2.61)$ & 0.034 \\
$\begin{array}{l}\text { Adjusted for age, sex, smoking, body mass index, } \mathrm{FEV}_{1} \text { (percent of predicted), } \\
\text { FVC (percent of predicted), } \mathrm{FEV}_{1} / \mathrm{FVC} \text { (percent), } \mathrm{PaO}_{2}, \mathrm{PaCO}_{2}, \mathrm{pH} \text {, ischemic } \\
\text { heart disease, history of myocardial infarction, heart rate, systolic and diastolic } \\
\text { blood pressure. }\end{array}$ & $1.63(1.03-2.58)$ & \\
\hline
\end{tabular}

COPD chronic obstructive pulmonary disease, $C H F$ congestive heart failure, $C l$ confidence interval, $F E V_{1}$ forced expiratory volume in one second, $F V C$ forced vital capacity, $\mathrm{FEV}_{1} / \mathrm{FVC}$ Tiffeneau, $\mathrm{PaO}_{2}$ partial arterial oxygen tension, $\mathrm{PaCO}_{2}$ partial arterial carbon dioxide tension

system, as well as the switch of immunoglobulins and the promotion of B cell growth and reproduction [28]. All of these data demonstrate that a deficit in either the $\mathrm{B}$ or $\mathrm{T}$ cell population or both could increase the risk of infection and, thus, morbidity and mortality in elderly patients. Lehtonen et al. suggested that, in very old people, both $\mathrm{T}$ and $\mathrm{B}$ cell function are significantly reduced and that there are major changes in lymphocyte subsets [15].

The mechanisms leading to the reduction in lymphocyte count and immunological impairment are still far from clear. Aging and COPD are associated with psychological stress [27].

It has been long known that psychological and physiological stresses result in a significant increase in systemic cortisol production [31]. The physiological diurnal variation and pulsatile pattern of secretion are thought to limit the lymphocyte-depleting effect of cortisol. However, elderly people secrete large amounts of cortisol, whose levels may remain elevated for a longer time than in younger adults $[32,33]$. Increased cortisol levels can result in a gradual decrease in relative lymphocyte count. Therefore, it may be supposed that a decrease in relative lymphocyte count in elderly patients with COPD, as a consequence of the combined action of age and cortisol pathway, would impair the distribution of white blood cells. Such a theory should be tested in further studies.

The hypothalamus-hypophysis-adrenal axis is a sensitive feedback system for various pathophysiological conditions leading to neurohumoral activation. Several lines of evidence demonstrate that severe COPD is associated with a generalized increase in circulating catecholamines and cytokines [34]. By increasing the production of selected cytokines, mainly of interleukin-6, cathecolamines indirectly stimulate the corticotropin-releasing hormone, which leads to increased secretion of cortisol and a consequent reduction in circulating lymphocytes [35]. Therefore, neurohumoral activation and the immune system demodulation produce a vicious circle that may worsen the prognosis in elderly patients with severe COPD and low relative lymphocyte count. The demonstration that plasma interleukin-6 levels increase with age [36-39] and in patients with COPD [40] supports this interpretation.
Furthermore, activation of the inflammatory systems could be responsible for the cachexia and hypermetabolic state found in some patients with severe COPD [34, 40]. A low relative lymphocyte count can be considered as a surrogate marker for malnutrition in patients with severe COPD, and thus as a negative prognostic factor. Fuenzalida et al. [41] demonstrated a partial recovery in immune system components, and lymphocyte count in particular, in patients with COPD who underwent a dedicated nutritional program. Therefore, the negative prognostic value of low lymphocyte count in elderly patients with COPD could be related to different conditions (cortisol and adrenergic hyperactivation, malnutrition, comorbidities, etc.), which impair the survival of such individuals. Thus, the relative lymphocyte count represents more than a simple marker of immunological deficit.

This study has some limitations, as follows: 1) lymphocyte subpopulations were not measured, and thus the respective prognostic role of deficits of the cellular and humoral immunity could not be assessed; 2) some degree of uncertainty exists in determining the cause of death in this kind of study, and, theoretically, this could affect the interpretation of the relationship between lymphopenia and mortality; 3) orthopnea and fluid retention are not uncommon in severe COPD complicated by hypoxemia and hypercapnia, and could simulate congestive heart failure. However, the stringent criteria used to diagnose congestive heart failure and the results of survival analysis for patients without congestive heart failure support the reliability of the current conclusions. Nevertheless, the proposed prognostic model should be tested in a population with only moderate COPD in order to limit further the potential confounding effect of congestive heart failure.

\section{Conclusions}

Relative lymphopenia has a homogeneous and strong effect on mortality across the whole follow-up period, but the inherent mechanisms remain to be clarified. To our knowledge, this study is the first to demonstrate that relative lymphopenia is associated with a poor prognosis in elderly patients with severe COPD. This finding seems worthy of attention because lymphocyte count is a simple, 
reproducible, widely available and inexpensive prognostic tool. Further research is needed to verify to which extent lymphopenia improves the prognostic definition based on well-established markers, as well as to assess the relationship linking lymphopenia with indices of neurohormonal activation and inflammation. Clarifying these issues would enable quantification of the weight of this new prognostic marker and, possibly, the design of interventions, e.g. immunological therapy, aimed at its correction.

\section{Additional files}

Additional file 1: Table S1. Evaluation of the reproducibility of measurements during the follow-up period. (DOCX $17 \mathrm{~kb}$ )

Additional file 2: Figure $\mathbf{S}$ 1. Correlation between relative lymphocyte count and 6-min walking test. (TIF $100 \mathrm{~kb}$ )

Additional file 3: Figure S2. Correlation between relative lymphocyte count and heart rate. (TIF $126 \mathrm{~kb}$ )

Additional file 4: Figure S3. Hazard ratio as a function of relative lymphocyte count threshold. (TIF $151 \mathrm{~kb}$ )

\section{Abbreviations}

ATS: American Thoracic Society; BMI: Body mass index; COPD: Chronic obstructive pulmonary disease; FEV1: Forced expiratory volume in the 1st second; FVC: Forced vital capacity; PaCO2: Partial arterial carbon dioxide tension; PaO2: Partial arterial oxygen tension

\section{Funding}

The study did not receive any funding

\section{Availability of data and materials}

The dataset is available from Dr. Domenico Acanfora, IRCCS Maugeri, Institute of Care and Scientific Research, Rehabilitation Institute of Telese Terme, Benevento, Italy, email: domenico.acanfora@fsm.it

\section{Authors' contributions}

MMC, DA, RAI conceived and designed the study, analysed and interpreted the data, drafted the article and critically reviewed its intellectual content, and finally approved the version to be submitted for publication. AZ, ID, PS, MC, CA, GP, ML, GC analysed the data, reviewed the article's intellectual content, and finally approved the version to be submitted for publication. All authors read and approved the final manuscript.

\section{Ethics approval and consent to participate}

The study was approved by the Institutional Board of IRCCS "S. Maugeri" TeleseTerme (BN) - Italy. Informed written consent was obtained from all individual participants included in the study.

The study did not involve any animals.

\section{Consent for publication}

Not applicable

\section{Competing interests}

The authors declare that they have no competing interests.

\section{Publisher's Note}

Springer Nature remains neutral with regard to jurisdictional claims in published maps and institutional affiliations.

\section{Author details}

${ }^{1}$ Maugeri Scientific Clinical Institutes, SpA SB, Institute of Care and Scientific Research, Rehabilitation Institute of TeleseTerme, Benevento, Italy. ${ }^{2}$ Section of Cardiovascular Diseases, Department of Emergency and Organ Transplantation, School of Medicine, University of Bari, Bari, Italy. ${ }^{3}$ Maugeri Scientific Clinical Institutes, SpA SB, Institute of Care and Scientific Research,
Rehabilitation Institute of Montescano, Pavia, Italy. ${ }^{4}$ San Francesco Hospital-TeleseTerme, Telese, BN, Italy. Institute of Internal Medicine, Chair of Geriatry, Policlinico Gemelli, School of Medicine, Rome, Italy.

Received: 19 February 2018 Accepted: 5 July 2018

Published online: 13 July 2018

\section{References}

1. Antonelli Incalzi R, Fuso L, De Rosa M, Forastiere F, Rapiti E, Nardecchia B, et al. Co-morbidity contributes to predict mortality of patients with chronic obstructive pulmonary disease. EurRespir J. 1997;10:2794-800.

2. Incalzi RA, Fuso L, De Rosa M, Di Napoli A, Basso S, Pagliari G, et al. Electrocardiographic signs of chronic corpulmonale: a negative prognostic finding in chronic obstructive pulmonary disease. Circulation. 1999;99:1600-5.

3. Song S, Yang PS, Kim TH, Uhm JS, Pak HN, Lee MH, et al. Relation of chronic obstructive pulmonary disease to cardiovascular disease in the general population. Am J Cardiol. 2017;120:1399-404.

4. Grolimund E, Kutz A, Marlowe RJ, Vögeli A, Alan M, Christ-Crain M, et al. Long-term prognosis in COPD exacerbation: role of biomarkers, clinical variables and exacerbation type. COPD. 2015:12:295-305.

5. Fuso L, Incalzi RA, Pistelli R, Muzzolon R, Valente S, Pagliari G, et al. Predicting mortality of patients hospitalized for acutely exacerbated chronic obstructive pulmonary disease. Am J Med. 1995;98:272-7.

6. Yamamoto E, Sugiyama S, Hirata Y, Tokitsu T, Tabata N, Fujisue K, et al. Prognostic significance of circulating leukocyte subtype counts in patients with coronary artery disease. Atherosclerosis. 2016;255:210-6.

7. Núñez J, Miñana G, Bodí V, Núñez E, Sanchis J, Husser O, et al. Low lymphocyte count and cardiovascular diseases. Curr Med Chem. 2011;18:3226-33.

8. Levinas T, Eshel E, Sharabi-Nov A, Marmur A, Dally N. Differentiating ischemic from non-ischemic chest pain using white blood cell-surface inflammatory and coagulation markers. J Thromb Thrombolysis. 2012;34:235-43.

9. Núñez J, Sanchis J, Bodí V, Núñez E, Mainar L, Heatta AM, et al. Relationship between low lymphocyte count and major cardiac events in patients with acute chest pain, a non-diagnostic electrocardiogram and normal troponin levels. Atherosclerosis. 2009:206:251-7.

10. Ommen SR, Hodge DO, Rodeheffer RJ, McGregor CG, Thomson SP, Gibbons RJ. Predictive power of the relative lymphocytes count in patients with advanced heart failure. Circulation. 1998;97:19-22.

11. Acanfora D, Gheorghiade M, Trojano L, Furgi G, Pasini E, Picone C, et al. Relative lymphocyte count: a prognostic indicator of mortality in elderly patients with congestive heart failure. Am Heart J. 2001;142:167-73.

12. Bender BS, Nagel JE, Adler WH, Andres R. Absolute peripheral blood lymphocyte count and subsequent mortality of elderly men: the Baltimore longitudinal study of aging. J Am Geriatr Soc. 1986;34:649-54.

13. Nelson DH, Sandberg AA, Palmer JG, Tyler FH. Blood levels of 17hydroxycorticosteroids following the administration of adrenal steroids and their relation to levels of circulating lymphocytes. J Clin Invest. 1952;31:843-9.

14. Thomson SP, McMahon LJ, Nugent CA. Endogenous cortisol: a regulator of the number of lymphocytes in peripheral blood. Clin Immunol Immunopathol. 1980;17:506-14.

15. Lehtonen L, Eskola J, Vainio O, Lehtonen A. Changes in lymphocyte subsets and immune competence in very advanced age. J Gerontol. 1990;45:M108-12.

16. Tavares SM, Junior Wde L, Lopes E, Silva MR. Normal lymphocyte immunophenotype in an elderly population. Rev Bras Hematol Hemoter. 2014;36:180-3.

17. Morley JE, Vellas B, van Kan GA, Anker SD, Bauer JM, Bernabei R, et al. Frailty consensus: a call to action. J Am Med Dir Assoc. 2013;14:392-7.

18. Lee SJ, Lee HR, Lee TW, Ju S, Lim S, Go SI, et al. Usefulness of neutrophil to lymphocyte ratio in patients with chronic obstructive pulmonary disease: a prospective observational study. Korean J Intern Med. 2016;31:891-8.

19. Furutate R, Ishii T, Motegi T, Hattori K, Kusunoki Y, Gemma A, et al. The neutrophil to lymphocyte ratio is related to disease severity and exacerbation in patients with chronic obstructive pulmonary disease. Intern Med. 2016;55:223-9.

20. Qaseem A, Wilt TJ, Weinberger SE, Hanania NA, Criner G, van der Molen T, et al. Diagnosis and management of stable chronic obstructive pulmonary disease: a clinical practice guideline update from American College of Physicians, American College of Chest Physicians, American Thoracic Society, and European Respiratory Society. Ann Intern Med. 2011:155:179-91.

21. Bakke PS, Rönmark E, Eagan T, Pistelli F, Annesi-Maesano I, Maly M, et al. Recommendations for epidemiological studies on COPD. Eur Respir J. 2011. 38:1261-77. 
22. [No authors listed]. ICD-9-CM : international classification of diseases, ninth revision, clinical modification, sixth edition. Centers for Disease Control and Prevention (US); Centers for Medicare \& Medicaid Services (US). Official version. [Atlanta, Ga.] : [Baltimore, Md.] : U.S. Dept. of Health and Human Services, Centers for Disease Control and Prevention; Centers for Medicare and Medicaid Services, [2011].

23. Carlson KJ, Lee DC, Goroll AH, Leahy M, Johnson RA. An analysis of physicians' reason for prescribing long-term digitalis therapy in outpatients. J Chron Dis. 1985;38:733-9.

24. Acanfora D, Trojano L, Maggi S, Furgi G, Rengo C, lannuzzi GL, et al. Development and validation of a clinical history form for the diagnosis of congestive heart failure. Aging Clin Exp Res. 1998;10:39-47.

25. Benedetti J, Yuen K, Young L. Life tables and survivor functions. In: Dixon WJ, editor. BMDP standard software manual. Berkley, CA: University of California Press; 1988. p. 689-718.

26. Snedecor GW, Cochran WG. Statistical methods. 8th ed. Ames: lowa State University Press; 1989. p. 333-73.

27. Guidi L, Tricerri A, Frasca D, Vangeli M, Errani AR, Bartoloni C. Psychoneuroimmunology and aging. Gerontology. 1998;44:247-61.

28. Rea IM, Stewart M, Campbell P, Alexander HD, Crockard AD, Morris TC. Changes in lymphocyte subsets, interleukin 2, and soluble interleukin 2 receptor in old and very old age. Gerontology. 1996;42:69-78.

29. Kishimoto T, Ishikaza K. Regulation of antibody response in vitro: V1 carrier specific helper cells of lgG and lgE antibody response. J Immunol. 1993;111: $720-31$

30. Vitetta ES, Berton MT, Burger C, Kepron M, Lee WT, Yin XM. Memory B and T cells. Ann Rev Immunol. 1991;9:193-217.

31. Taylor AL, Fishman LM. Corticotropin-releasing hormone. N Egl J Med. 1988; 319:213-22.

32. Simpkins JW, Millard WJ. Influence of age on neurotrasmitter function. Endocrinol Metab Clin North Am. 1987;16:893.

33. Martin JB, Reichlin S. Clinical neuroendocrinology. 2nd ed. Philadelphia: F. A. Davis; 1987.

34. Hofford JM, Milakofsky L, Vogel WH, Sacher RS, Savage GJ, Pell S. The nutritional status in advanced emphysema associated with chronic bronchitis. A study of aminoacid and catecholamine levels. Am Rev Respir Dis. 1990:141:902-8.

35. Papanicolaou DA, Wilder RL, Manolagas SC, Chrousos GP. The pathophysiologic roles of interleukin-6 in human disease. Ann Intern Med. 1998;128:127-37.

36. Hager K, Machein U, Krieger S, Platt D, Seefried G, Bauer J. Interleukin-6 and selected plasma proteins in healthy persons of different ages. Neurobiol Aging. 1994;15:771-2.

37. Ershler WB, Sun WH, Binkley N, Gravenstein S, Volk MJ, Kamoske G, et al. Interleukin-6 and aging: blood levels and mononuclear cell production increase with advancing age and in vitro production is modifiable by dietary restriction. Lymphokine Cytokine Res. 1993;12:225-30.

38. Chiappelli M, Tampieri C, Tumini E, Porcellini E, Caldarera CM, Nanni S, et al. Interleukin-6 gene polymorphism is an age-dependent risk factor for myocardial infarction in men. Int J Immunogenet. 2005:32:349-53.

39. Ershler WB, Keller ET. Age-associated increased interleukin-6 gene expression, late-life diseases, and frailty. Annu Rev Med. 2000;51:245-70.

40. Schols AM, Buurman WA, Staal van den Brekel AJ, Dentener MA, Wouters EF. Evidence for a relation between metabolic derangements and increased levels of inflammatory mediators in a subgroup of patients with chronic obstructive pulmonary disease. Thorax. 1996;51:819-24.

41. Fuenzalida CE, Petty TL, Jones ML, Jarrett S, Harbeck RJ, Terry RW, et al. The immune response to short-term nutritional intervention in advanced chronic obstructive pulmonary disease. Am Rev Respir Dis. 1990;142:49-56

Ready to submit your research? Choose BMC and benefit from:

- fast, convenient online submission

- thorough peer review by experienced researchers in your field

- rapid publication on acceptance

- support for research data, including large and complex data types

- gold Open Access which fosters wider collaboration and increased citations

- maximum visibility for your research: over $100 \mathrm{M}$ website views per year

At BMC, research is always in progress.

Learn more biomedcentral.com/submissions 